\title{
FAKTOR-FAKTOR YANG MEMPENGARUHI KUALITAS LAPORAN KEUANGAN PEMERINTAH DAERAH DALAM PENGELOLAAN BARANG MILIK DAERAH
}

\author{
Oleh : \\ Christina, SE, M.Si \\ Fakultas Ekonomi Program Studi Akuntansi \\ Universitas Satya Negara Indonesia
}

\begin{abstract}
ABSTRAK
Tujuan penelitian ini untuk menganalisis pengaruh parsial dan simultan variabel kompetensi dan pengalaman dalam mengelola barang milik daerah terhadap kualitas laporan keuangan pemerintah daerah. Jenis Penelitian ini adalah penelitian asosiatif yang bersifat kausal. Populasi dalam penelitian ini adalah pegawai yang terlibat dalam pegelolaan barang milik daerah Kabupaten Bekasi. Data yang diolah adalah data primer yang diperoleh dengan cara mengolah data kuesioner sebanyak 60 responden yang terdiri dari pengurus barang dan pengurus barang-barang pembantu di Pemerintah Daerah kabupaten Bekasi. Data dianalisis dengan metode analisis regresi berganda dengan menggunakan program SPSS. Hasil penelitian membuktikan bahwa secara parsial etika tidak berpengaruh secara signifikan terhadap kualitas laporan keuangan pemerintah daerah, sedangkan kompetensi dan pengalaman dalam pengelolaan barang milik daerah berpengaruh secara signifikan terhadap kualitas laporan keuangan pemerintah daerah Kabupaten Bekasi. Sementara itu secara simultan etika, kompetensi dan pengalaman dalam pengelolaan barang milik daerah berpengaruh secara signifikan terhadap kualitas laporan keuangan pemerintah daerah.

Kata kunci : Kualitas Laporan Keuangan, Pengelolaan Barang Milik Daerah, Etika, Kompetensi, dan Pengalaman
\end{abstract}

\section{ABSTRACT}

The purpose of this study is to analyze the effect of partial and simultaneous competency variables and experience in managing regional property to the quality of local government financial reports. This type of research is associative research that is causal. The population in this study are employees involved in managing the property of the Bekasi Regency area. Data processed is primary data obtained by processing questionnaire data as many as 60 respondents consisting of goods administrators and administrators of auxiliary goods in the Bekasi District Government. Data were analyzed by multiple regression analysis using the SPSS program. The results of the research prove that partially ethics does not significantly influence the quality of local government financial statements, while competence and experience in managing regional property have a significant effect on the quality of the Bekasi district government financial statements. Meanwhile, simultaneously ethics, competence and experience in managing regional property have a significant effect on the quality of local government financial reports.

Keywords : Quality of Financial Statements, Management of Regional Property, Ethics, Competence, and Experience 


\section{PENDAHULUAN}

Pengelolaan Barang Milik Daerah merupakan hal yang sangat penting karena pengelolaan Barang Milik Daerah yang buruk dapat berdampak buruk bagi laporan keuangan pemerintah daerah tersebut. Aset tetap/Barang Milik Daerah memiliki fungsi yang sangat penting dalam penyelenggaraan pemerintahan, tetapi dalam pelaksanaan pengelolaannya sering kali terdapat berbagai persoalanAset/barang daerah merupakan suatu potensi ekonomi serta sumber daya yang mutlak diperlukan dalam penyelenggaraan pemerintahan daerah. Hal ini dikarenakan apabila barang daerah dikelola dengan baik dan benar, akan terwujud pengelolaan barang daerah yang transparan, efisien, dan akuntabel sehingga dapat memberikan kontribusi bagi pemerintah daerah sebagai sumber pendapatan sekaligus dapat menunjang peran dan fungsi pemerintah daerah sebagai pemberi pelayanan publik kepada masyarakat.

Dalam rangka mendukung pelimpahan kewenangan proses pengelolaan barang milik daerah, maka pemerintah pusat telah mengeluarkan peraturan menteri dalam negeri nomor 17 tahun 2007, dan telah diubah dengan peraturan terbaru yaitu peraturan menteri dalam negeri nomor 19 tahun 2016 tentang Pedoman Pengelolaan Barang Milik Daerah, peraturan ini menuntut suatu perubahan mendasar dibidang pengelolaan dan pertanggungjawaban barang milik daerah dan telah memunculkan optimisme baru dalam pengelolaan aset daerah yang lebih tertib, akuntabel dan transparan kedepannya dengan mengedepankan prinsip good governance.

Laporan keuangan pemerintah daerah merupakan pertanggungjawaban pelaksanaan anggaran yang merupakan tanggungjawab pemerintah daerah yang bersangkutan, untuk itu pemerintah daerah harus membuat pernyataan tertulis bahwa laporan keuangan dsajikan berdasarkan Sistem Pengendalian Intern yang memadai dan sesuai dengan Standar Akuntansi Pemerintahan. Pengawasan terhadap keuangan daerah merupakan bagian yang tidak dapat dipisahkan baik pengawasan internal maupun eksternal, dalam hal ini pengawasan eksternal oleh Badan Pemeriksa Keuangan. Pemeriksaan Laporan Keuangan Tahunan oleh BPK akan ditindaklanjuti dengan pemberian opini, oleh sebab itu untuk mendapatkan opini yang baik yaitu Wajar Tanpa Pengecualian (WTP), maka pengelolaan barang milik daerah yang merupakan bagian integral dari laporan keuangan harus dilakukan dengan optimal dan sesuai dengan Standar Akuntansi Pemerintahan dan peraturan perundang-undangan yang berlaku.

Permasalahan dalam pembuatan Laporan Keuangan dan Laporan Barang Milik Daerah bisa terjadi dalam Sistem Pengendalian Intern (SPI). Kepatuhan terhadap ketentuan perundang-undangan maupun dalam penyusunan laporan keuangan, etika para pegawai dalam menerapkan kepatuhan terhadap kode etik pegawai menjadi suatu permasalahan dalam mengelola barang milik daerah.

Etika sangat diperlukan karena akan mempengaruhi hasil pekerjaan tersebut. Aparatur pemerintah pada dasarnya adalah pelayan publik. Fokus utama dalam etika pelayanan publik adalah aparatur telah mengambil keputusan dan berperilaku yang dapat dibenarkan dari sudut pandang etika yang salah satunya adalah mmemberikan transparansi, jujur dan akuntabel dalam sebuah pelaporan, baik pelaporan barang milik daerah maupun pelaporan keuangan yang berkualitas bagi masyarakat.

Pengalaman ialah sesuatu yang pernah dialami (dijalani, dirasai, ditangggung dan sebagainya) bisa berupa peristiwa yang baik maupun yang buruk (KBBI, 2005). Pengalaman merupakan guru terbaik, pepatah ini mengandung maksud bahwa pengalaman dapat dijadikan sebagai sumber pengetahuan, atau pengalaman merupakan suatu cara untuk memperoleh kebenaran pengetahuan. Dengan demikian dapat disimpulkan bahwa pengalaman adalah tingkat penguasaan pengetahuan dan ketrampilan pegawai dalam pekerjaannya. Pengalaman pegawai dalam mengelola barang milik daerah akan ikut mematangkan pegawai yang 
bersangkutan dalam menghadapi masalah-masalahnya khususnya dalam penyusunan laporan keuangan.

Untuk memperoleh laporan keuangan yang berkualitas dibutuhkan pegawai yang mempunyai kompetensi dalam membuat laporan keuangan, maupuan dalam mengelolan barang milik daerah sebagai bagian yang terintegrasi dengan laporan keuangan sehingga sangat dibutuhkan pegawai untuk mempunyai kompetensi dimana kualitas individu tersebut akan menghasilkan kesuksesan dalam pekerjaannya. Sampai dengan tahun 2013 Pemerintah Daerah Kabupaten Bekasi belum pernah sekalipun menerima opini Wajar Tanpa Pengecualian (WTP) akibat tidak memadainya pengelolaan barang milik daerah sehingga terdapat beberapa hal yang dikecualikan ( belum diyakini kewajaran pelaporannya).

Berdasarkan Laporan hasil Pemeriksaan atas Laporan Keuangan Pemerintah Daerah (LKPD) tahun anggaran 2014-2016 meskipun sudah memperoleh opini Wajar Tanpa Pengecualian, pengelolaan barang milik daerah termasuk didalamnya penatausahaan barang milik daerah pada pemerintah daerah kabupaten bekasi dilaporkan masih belum memadai yaitu masih terdapat aset yang dilaporkan dalam pelaporan keuangan dengan rincian barang milik daerah yang tidak ditemukan keberadaannya, tanpa keterangan ataupun identitas yang lengkap, terdapat tanah sebagai bagian dari barang milik daerah yang belum bersertifikat, barang milik daerah yang dicatat dan dilaporkan dalam bentuk paket sehingga masih belum dapat diyakini sepenuhnya atas kewajaran nilai penyusutannya, serta permasalahan lainnya.

Dari uraian diatas, penulis terdorong untuk melakukan penelitian dengan judul

"Faktor-Faktor Yang Mempengaruhi Kualitas Laporan Keuangan Pemerintah Daerah Dalam Pengelolaan Barang Milik Daerah"

\section{Perumusan Masalah}

Berdasarkan latar belakang diatas maka dapat dirumuskan masalah penelitian sebagai berikut :

1. Apakah etika, kompetensi, dan pengalaman dalam pengelolaan barang milik daerah berpengaruh secara parsial terhadap kualitas laporan keuangan pemerintah daerah?

2. Apakah etika, kompetensi, dan pengalaman dalam pengelolaan barang milik daerah berpengaruh secara simultan terhadap kualitas laporan keuangan pemerintah daerah?

\section{Tujuan penelitian}

Tujuan penelitian ini adalah sebagai berikut :

1. Untuk mengetahui pengaruh etika, kompetensi, dan pengalaman dalam pengelolaan barang milik daerah secara parsial terhadap kualitas laporan keuangan pemerintah daerah.

2. Untuk mengetahui pengaruh etika, kompetensi, dan pengalaman dalam pengelolaan barang milik daerah secara simultan terhadap kualitas laporan keuangan pemerintah daerah.

\section{Manfaat Penelitian}

1. Bagi akademisi, menjadi bahan literatur untuk pengembangan penelitian selanjutnya tentang kualitas laporan keuangan pemerintah daerah.

2. Bagi peneliti, dapat memberikan kontribusi keilmuan dan mengembangkan wawasan dibidang akuntansi sektor publik mengenai faktor-faktor yang mempengaruhi kualitas laporan keuangan pemerintah daerah.

3. Bagi Pemerintah Daerah, menjadi bahan evaluasi dan dapat dijadikan gambaran bagi pemda dalam meningkatkan kualitas laporan keuangan pemda. 


\section{Pengertian Laporan Keuangan Pemerintah Daerah \\ LANDASAN TEORI}

Laporan keuangan merupakan bentuk pertanggungjawaban atas kepengurusan sumber daya ekonomi yang dimiliki oleh suatu entitas. Menurut Peraturan Menteri Dalam Negeri Nomor 13 Tahun 2006, tentang Pedoman Pengelolaan Keuangan Daerah, dalam ketentuan umumnya menyebutkan bahwa yang dimaksud dengan keuangan daerah adalah semua hak dan kewajiban daerah dalam rangka penyelenggaraan pemerintah daerah yang dapat dinilai dengan uang termasuk di dalamnya segala bentuk kekayaan yangberhubungan dengan hak dan kewajiban daerah tersebut. Selanjutnya dikatakan pula bahwa, pengelolaan keuangan daerah dilakukan dengan tertib, taat pada peraturan perundang-undangan, efektif, efisien, ekonomis, transparan dan bertanggungjawab dengan memperhatikan asas keadilan, kepatutan dan manfaat untuk masyarakat.

Berdasarkan Peraturan Pemerintah No. 71 Tahun 2010 pengertian laporan keuangan adalah laporan yang terstruktur mengenai posisi keuangan dan transaksi-transaksi yang dilakukan oleh suatu entitas pelaporan. Entitas pelaporan adalah unit pemerintahan yang terdiri dari satu atau lebih entitas akuntansi yang menurut ketentuan peraturan perundangundangan wajib menyampaikan laporan pertanggungjawaban, berupa laporan keuangan yang bertujuan umum, yang terdiri dari:

a. Pemerintah pusat;

b. Pemerintah daerah;

c. Masing-masing kementerian negara atau lembaga di lingkungan pemerintah pusat;

d. Suatu organisasi di lingkungan pemerintah pusat/daerah atau organisasi lainnya jika menurut peraturan perundang-undangan satuan organisasi dimaksud wajib menyampaikan laporan keuangan

\section{Jenis-Jenis Laporan Keuangan Pemerintah Daerah}

Laporan keuangan pemerintah daerah adalah suatu bentuk pertanggungjawaban pmerintah daerah kepada stakeholder yang didalamnya mencakup berbagai macam pekerjaan yang membutuhkan keuangan, termasuk komponen aset yang tercermin dalam neraca (kini disebut sebagai "laporan posisi keuangan") daerah dimana setiap tahun dibuatkan laporannya setelah pelaksanaan anggaran (M.Yusuf.2010)

Menurut Peraturan Pemerintah Nomor 72 tahun 2010 tentang standar akuntansi pemerintah, laporan kuangan pemerintahan terdiri atas 7 jenis laporan, yaitu sebagai berikut :

a) Laporan Realisasi Anggaran

b) Laporan Perubahan Saldo Anggaran Lebih

c) Laporan Operasional

d) Laporan Perubahan Ekuitas

e) Neraca / Laporan Posisi Keuangan

f) Laporan Arus Kas

g) Catatan atas Laporan Keuangan

\section{Kualitas Laporan Keuangan Pemeintah Daerah}

Laporan keuangan daerah akan diperiksa oleh Badan Pemeriksa Keuangan pada setiap tahun anggaran untuk memberikan opini terhadap hasil pemeriksaan atas laporan keuangan pemerintah daerah. Menurut undang-undang nomor 15 tahun 2004 tentang pemeriksaan pengelolaan dan tanggungjawab keuangan Negara pasal 1, opini adalah pernyataan profesional sebagai kesimpulan suatu pemeriksaan mengenai tingkat kewajaran informasi yang disajikan dalam laporan keuangan.

Dalam undang-undang nomor 15 tahun 2004 pasal 4 tentang pemeriksaan pengelolaan dan tanggung jawab keuangan Negara, BPK antara lain melakukan pemeriksaan keuangan. 
Pemeriksaan keuangan adalah pemeriksaan atas laporan keuangan yang bertujuan memberikan keyakinan yang memadai (reasonable assurance) bahwa laporan keuangan telah disajikan secara wajar dalam semua hal yang material sesuai dengan prinsip akuntansi yang berlaku umum di Indonesia.

Menurut keputusan BPK RI Nomor 4/K/I-XIII/29/2012 tentang jenis opini terdapat empat jenis opini yang diberikan oleh pemeriksa, yaitu:

1. Wajar Tanpa Pengecualian (WTP) memuat suatu pernyataan bahwa laporan keuangan menyajikan secara wajar, dalam segala hal yang material sesua dengan Standar Profesional Akuntan Publik (SPAP) yang diberlakukan, BPK dapat memberikan opini WTP dengan paragraph penjelas karena keadaan tertentu sehingga mengharuskan pemeriksa menambahkan suatu paragraph penjelasan dalam laporan hasil pemeriksaan sebagai modifikasi dari opini WTP.

2. Wajar Dengan Pengecualian (WDP) memuat suatu pernyataan bahwa laporan keuangan menyajikan secara wajar, dalam semua hal material sesuai dengan SAP, kecuali untuk dampak hal-hal yang berhubungan dengan yang dikecualikan.

3. Tidak Wajar memuat suatu pernyataan bahwa laporan keuangan tidak menyajikan secara wajar dalam semua hal yang material sesuai dengan SAP

4. Pernyataan menolak memberikan opini atau tidak memberikan pendapat (TMP) menyatakan bahwa pemeriksa tidak menyatakan opini atas laporan keuangan.

Kriteria dan unsur-unsur kualtas atau nilai informasi dari laporan keuangan pemerintah telah ditentukan dalam Peraturan Pemerintah Nomor 71 tahun 2010 tentang Standar Akuntansi pmerintah, ada empat karateristik kualitatif laporan keuangan yaitu :

1. Relevan

2. Andal

3. Dapat dibandingkan

4. Dapat dipahami

\section{Pengelolaan Barang Milik Daerah}

Berdasarkan Peraturan Pemerintah Nomor 6 tahun 2006 tentang Pengelolaan Barang Milik Negara / Daerah, yang diberi nama aset adalah barang. Selanjutnya dalam Peraturan Presiden Nomor 54 tahun 2010 dijelaskan pengertian barang adalah setiap benda baik berwujud maupun tidak berwujud, bergerak maupun tidak bergerak, yang dapat diperdagangkan, dipakai, dipergunakan atau dimanfaatkan oleh Pengguna Barang.

Seiring dengan perkembangan jaman, peraturan mengenai barang milik daerah pun mengalami beberapa perubahan, yang diawali dengan diterbitkannya Peraturan Menteri Dalam Negeri Nomor 17 tahun 2007 tentang Pedoman Teknis Pengelolaan Barang Milik Daerah, menyebutkan bahwa yang dimaksud dengan Barang Milik Daerah (BMD) adalah semua barang yang dibeli atau diperoleh atas beban Anggaran Pendapatan dan Belanja Daerah atau perolehan lainnya yang sah antara lain, barang yang diperoleh dari hibah/sumbangan atau sejenisnya, barang diperoleh sebagai pelaksanaan dari perjanjian/kontrak, barang yang diperoleh berdasarkan ketentuan undang-undang atau barang yang diperoleh berdasarkan putusan pengadilan yang telah memperoleh kekuatan hukum tetap. Peraturan mengenai Barang Milik Daerah yang terbaru yaitu Peraturan Menteri Dalam Negeri nomor 19 tahun 2016 juga menyebutkan hal yang sama, yaitu bahwa barang milik daerah adalah semua barang yang dibeli atau diperoleh atas beban APBD atau perolehan lainnya yang sah. Peraturan Pemerintah Nomor 6 Tahun 2006 tentang Pengelolaan Barang Milik Negara / Daerah pasal 3 ayat (2) menyebutkan bahwa pengelolaan barang milik daerah meliputi perencanaan kebutuhan dan penganggaran, pengadaan, penggunaan, pemanfaatan, pengamanan dan pemeliharaan, penilaian, penghapusan, pemindahtangannan, penatausahaan, 
pembinaan dan pengawasan. Sedangkan menurut Peraturan Menteri Dalam Negeri Nomor 17 tahun 2007 pengelolaan barang milik daerah meliputi perencanaa kebutuhan dan penganggaran, pengadaan, penerimaan, penyimpanan dan penyaluran, penggunaan, penatausahaan, pemanfaatan, pengamanan dan pemeliharaan, penilaian, penghapusan, pemindahtanganan, pembinaan, pengawasan dan pengendalian, pembiayaan dan tuntutan ganti rugi. Selanjutnya menurut peraturan terbaru yaitu Peraturan Menteri Dalam Negeri Nomor 19 tahun 2016 pengelolaan Barang Milik Daerah meliputi perencanaan kebutuhan dan penganggaran, pengadaan, penggunaan, pemanfaatan, pengamanan dan pemeliharaan, penilaian, pemindahtangan, pemusnahan, penghapusan, penatausahaan, pembinaan, pengawasan dan pengendalian serta tuntutan gantirugi. Penatausahaan meliputi pembukuan, inventarisasi dan pelaporan. Pada peraturan terbaru terdapat dua prosedur tambahan yang tidak ada pada peraturan sebelumnya yaitu pemeliharaa dan pemusnahan.

\section{Etika}

Etika berasal dari bahasa Yunani ethos (kata tunggal) yang berarti tempat tinggal, padang rumput, kandang, kebiasaan, adat, watak, sikap, cara berfikir. Bentuk jamaknya aadalah ta, etha, yang berarti adat kebiasaan. Menurut Bertens ada dua pengertian etika, yakni etika sebagai praktis dan etika sebagai reflesi. Sebagai praktis, etika berarti nilai-nilai dan norma-norma, moral yang baik dipraktikkan atau justru tidak dipraktikkan, walaupun seharusnya dipraktikkan. Etika sebagai praktis sama artinya dengan moral atau moralitas, yaitu apa yang harus dilakukan, tidak boleh dilakukan, pantas dilakukan, dan sebagainya. Etika sebagai refleksi adalah pemikiran moral, etika bagi seseorang terwujud dalam kesadaran modal yang memuat keyakinan benar atau tidak sesuatu. Perasaan yang muncul bahwa ia akan salah melakukan sesuatu yang diyakini tidak benar berangkat dari norma-norma dan self-respect (menghargai diri) bila ia meninggalkannya.

Indikator Etika Apartur Sipil Negara antara lain sebagai berikut :

a. Bekerja dengan penuh pengabdian dan tanggungjawab

b. Berperilaku sesuai etika

c. Menjaga nama baik kepada pribadi, atasan dan instansi.

d. Menjunjung tinggi moral dalam melakukan pekerjaan.

Pengelola Barang Milik Daerah merupakan bagian dari aparatur sipil Negara yang mempunyai tugas dalam pengelolaan barang milik daerah, untuk itu indikator etika tersebut berlaku juga kepada pengelola barang milik daerah.

\section{Kompetensi}

Menurut pendapat Gulo (2014), kompetensi terdiri dari dua aspek yang saling berinteraksi, yaitu aspek yang tampak atau disebut performance (penampilan) dan aspek yang tidak tampak atau yang disebut aspek rasional. Performance ditunjukkan dalam bentuk tingkah laku yang dapat didemontrasikan sehingga dapat, diamati dan dirasakan, sedangkan aspek rasional tidak dapat diamati karena tidak tampil dalam bentuk perilaku empiris.

Menurut Peraturan Pemerintah Nomor 101 pasal 3 tentang Pendidikan dan Pelatihan Jabatan Pegawai Negeri Sipil, menyebutkan bahwa kompetensi dan karakteristika yang dimilik oelh seorang pegawai negeri sipil berupa pengetahuan, sikap perilaku yang diperlukan dalam tugas dan jabatannya. Dengan demikian kompetensi yang dimiliki pegawai berhubungan langsung dengan pekerjaan yang sesuai dengan kemampuan dan pengetahuan yang dimiliki sehingga dengan kompetensi yang dimiliki akan menentukan jabatan yang sesuai didalam organisasi.

Dalam bukunya yang berjudul kompentensi plus, Hutapea (2008) menyebutkan indicator kompetensi, antara lain :

a. Pengetahuan yang berkaitan dengan pekerjaan yang meliputi : 
1) Mengetahui dan memahami pengetahuan dibidangya masing-masing yang menyangkut tugas dan tanggungjawab dalam bekerja

2) Mengetahui tupoksi organisasi instansi

3) Mengetahui bagaimana menggunakan informasi, peralatan dan teknik yang tepat dan benar

b. Keterampilan individu, meliputi :

1) Kemampuan menyelesaikan tugas dengan baik

2) Kemampuan dalam mengatasi masalah

3) Kemampuan menentukan prioritas masalah

4) Kemampuan memberikan informasi pelayanan

c. Sikap Kerja, meliputi :

1) Mempunyai kreativitas dalam bekerja

2) Adanya semangat kerja yang tinggi

3) Mempunyai kemampuan dalam perencanaan/pengorganisasian

\section{Pengalaman}

Pengalaman merupakan suatu proses pembelajaran dan pertambahan perkembangan potensi bertingkah laku baik dari pendidikan formal maupun nonformal atau bias diartikan sebagai suatu proses yang membawa seseorang kepada suatu pola tingkah laku yang lebih tinggi. Suatu pembelajaran juga mencakup perubahan yang relative lebih tepat dari perilaku yang diakibatkan pengalaman, pemahaman dan praktek (Knoers \& Haditono, 2009).

Menurut Foster (2001), ada beberapa hal yang dapat digunakan untuk menetukan berpengalaman tidaknya seorang karyawan yang sekaligus sebagai indicator pengalaman kerja, yang meliputi :

a. Lama waktu / masa kerja.

b. Tingkat pengetahuan dan ketrampilan yang dimiliki.

c. Penguasaan terhadap pekerjaan dan peralatan.

\section{Desain Penelitian}

\section{METODE PENELITIAN}

Penelitian ini merupakan penelitian Kausal, yaitu penelitian yang mencari pengaruh antara satu atau lebih variable bebas (Independent Variable) terhadap variable terikat (Dependent Variable ).

\section{Jenis Data}

Data yang digunakan merupakan data primer, yaitu data yang diperoleh langsung dari objek yang diteliti dan digunakan untuk mengukur variabel independen (etika, kompetensi, dan pengalaman) serta variabel dependen (kualitas laporan keuangan pemerintah daerah) yang diambil dari individu atau perseorangan seperti hasil penyebaran kuesioner.

\section{Populasi dan Sampel Penelitian}

Populasi adalah wilayah generalisasi yang terdiri atas objek / subjek yang mempunyai kualitas dan karakteristik tertentu yang ditetapkan oleh peneliti untuk mempelajari dan kemudian ditarik kesimpulan (Sugiyono 2013). Populasi bukan sekedar jumlah yang ada pada objek atau subjek tersebut, tetapi meliputi seluruh karakteristik atau sifat yang dimiliki oleh objek atau subjek tersebut. Populasi dalam penelitian ini adalah seluruh karyawan dan pihakpihak yang berhubungan dengan pengelolaan barang milik daerah dan penyusunan Laporan Keuangan Pemerintah Daerah Kabupaten Bekasi.

Sampel yang akan diambil dari populasi tersebut diatas yang betul-betul representatif atau dapat mewakilinya. Dalam penelitian ini yang menjadi sampel adalah seluruh Pengurus 
Barang pada masing-masing Perangkat Daerah yang ada di Kabupaten Bekasi yang telah ditugaskan minimal selama 2 tahun. Teknik yang digunakan dalam pengambilan sampel pada penelitian ini dengan menggunakan teknik non probability sampling, yaitu pengambilan sampel yang ditentukan sendiri oleh peneliti atau menurut pertimbangan pakar.

\section{Variabel Penelitian}

1. Variabel dependen (Y)

Variabel terikat yang digunakan dalam penelitian ini adalah kualitas laporan keuangan pemerintah daerah.

2. Variabel independen $(\mathrm{X})$

Variabel bebas dalam penelitian ini adalah etika (X1), kompetensi (X2), dan pengalaman (X3).

\section{Kerangka Pemikiran Teoritis}

Berdasarkan teori yang telah diuraikan sebelumnya maka dapat disusun kerangka pemikiran sebagai berikut :

\section{Hipotesis}

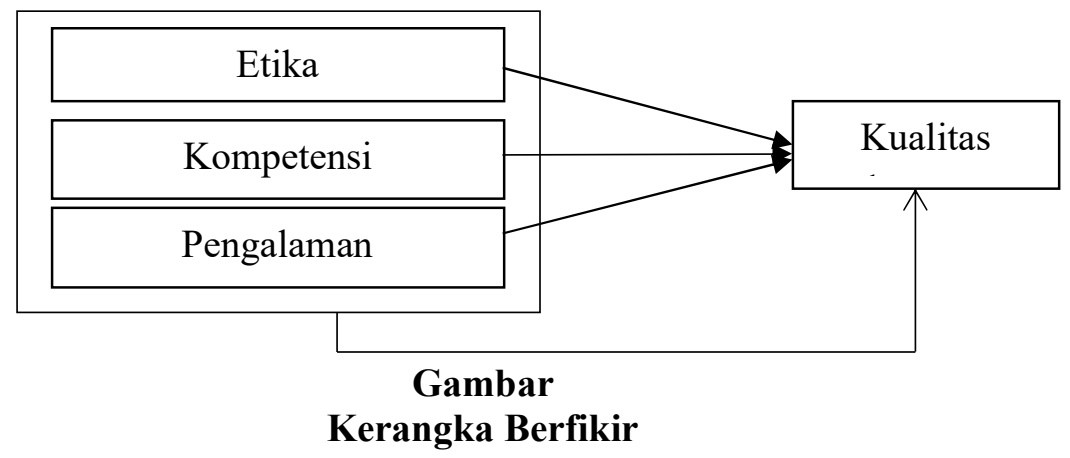

1) Hipotesis Ho1 : Etika dalam mengelola barang milik daerah tidak berpengaruh terhadap kualitas laporan keuangan

2) Hipotesis Ha1 : Etika dalam mengelola barang milik daerah berpengaruh terhadap kualitas laporan keuangan

3) Hipotesis Ho2 : Kompetensi dalam mengelola barang milik daerah tidak berpengaruh terhadap kualitas laporan keuangan

4) Hipotesis Ha2 : Kompetensi dalam mengelola barang milik daerah berpengaruh terhadap kualitas laporan keuangan

5) Hipotesis Ho3 : Pengalaman dalam mengelola barang milik daerah tidak berpengaruh terhadap kualitas laporan keuangan

6) Hipotesis Ha3 : Pengalaman dalam mengelola barang milik daerah berpengaruh terhadap kualitas laporan keuangan

7) Hipotesis Ho4 : Etika, kompetemsi dan pengalaman dalam mengelola barang milik daerah secara bersama-sama tidak berpengaruh terhadap kualitas laporan keuangan

8) Hipotesis Ha4 : Etika, kompetemsi dan pengalaman dalam mengelola barang milik daerah secara bersama-sama berpengaruh terhadap kualitas laporan keuangan

\section{ANALISIS HASIL DAN PEMBAHASAN}

Responden dalam penelitian ini adalah pegawai yang bertugas sebagai pengurus barang dan pengurus barang pembantu. Pengurus barang adalah staf pelaksana yang bertugas dalam mengelola barang milik daerah pada lingkup pengguna barang atau secara sederhana 
pada tingkat instansi/satuan kerja perangkat daerah sebagai contoh pengurus barang pada Dinas Kesehatan, sedangkan pengurus barang pembantu adalah staf pelaksana yang bertugas dalam mengelola barang milik daerah pada lingkup kuasa pengguna barang atau secara sederhana pada pada tingkat unit instansi sebagai contoh pengurus barang pembantu pada bagian humas sekretariat daerah. Adapun tugas dan fungsi baik pengurus barang maupun pengurus barang pembantu adalah sama.

Tingkat pengembalian kuesioner pada penelitian ini tinggi, dikarenakan peneliti mendistribusikan secara langsung dan juga menggunakan media elektronik dengan memanfaatkan google form. Kuesioner yang disebarkan kepada responden adalah sebanyak sebanyak 71 responden dengan tingkat pengembalian sebanyak 100\%. Distribusi hasil penelitian ini disajikan sebagai berikut:

\section{Tabel}

Deskripsi Kuesioner

\begin{tabular}{|c|c|c|c|c|}
\hline Responden & $\begin{array}{c}\text { Kuesioner } \\
\text { Disebarkan }\end{array}$ & $\begin{array}{c}\text { Kuesioner } \\
\text { Kembali }\end{array}$ & $\begin{array}{c}\text { Kuesioner } \\
\text { Gugur }\end{array}$ & $\begin{array}{c}\text { Kuesioner yang } \\
\text { diolah }\end{array}$ \\
\hline Pengurus Barang & 60 & 60 & 11 & 49 \\
\hline Pengurus Barang Pembantu & 11 & 11 & - & 11 \\
\hline Total & $\mathbf{7 1}$ & $\mathbf{7 1}$ & $\mathbf{1 1}$ & $\mathbf{6 0}$ \\
\hline
\end{tabular}

Sumber: Data primer diolah, 2019

Dari tabel di atas dapat diketahui bahwa kuesioner yang disebar sebanyak 71 rangkap dengan tingkat pengembalian 100\%.Terdapat data yang tidak sesuai dengan syarat pemilihan sampel, yakni sebanyak 8 data yang merupakan responden dengan masa jabatan sebagai pengurus barang kurang dari 2 tahun, serta 3 kuesioner yang tidak menggambarkan keadaan yang sebenarnya, sehingga kuesioner tersebut tidak dapat dipakai untuk menjadi data penelitian. Sehingga nantinya data yang dapat diolah untuk menguji penelitian ini adalah sebanyak 60 responden.

\section{Statistik Deskriptif}

\begin{tabular}{|c|c|c|c|c|c|}
\hline \multicolumn{6}{|c|}{ Statistiks } \\
\hline & & Etika & kompetensi & pengalaman & kualitas \\
\hline \multirow[t]{2}{*}{$\mathrm{N}$} & Valid & 60 & 60 & 60 & 60 \\
\hline & Missing & 0 & 0 & 0 & 0 \\
\hline \multicolumn{2}{|c|}{ Mean } & 39.8333 & 31.7667 & 32.5500 & 38.8167 \\
\hline \multicolumn{2}{|c|}{ Median } & 40.0000 & 32.0000 & 33.0000 & 39.0000 \\
\hline \multicolumn{2}{|c|}{ Std. Deviation } & 4.69824 & 3.30570 & 3.78859 & 3.69375 \\
\hline \multicolumn{2}{|c|}{ Minimum } & 30.00 & 25.00 & 25.00 & 31.00 \\
\hline \multicolumn{2}{|c|}{ Maximum } & 50.00 & 40.00 & 40.00 & 45.00 \\
\hline
\end{tabular}

\section{Uji Validitas}

Menurut Marsun yang dikutip oleh Sugiyono (2008 : 124) menyatakan teknik korelasi untuk menganalisis validitas item, sampai sekarang merupakan teknik yang paling banyak digunakan. Item mempunyai korelasi positif dengan skor total serta korelasi yang tinggi menujukkan bahwa item tersebut memiliki validitas yang tinggi pula. Syarat minimum adalah apabila $r=0,3$. jadi kalau korelasi terjadi antara butir dengan skor total kurang dari 0,3 maka butir dalam instrumen tersebut dinyatakan tidak valid.

$$
\begin{aligned}
& \text { Rumus : } r=\frac{N\left(\sum x y\right)-\left(\sum x \cdot \sum y\right)}{\sqrt{\left\{N \sum x^{2}-\left(\sum x^{2}\right)\left(N \sum y^{2}-\left(\sum y\right)^{2}\right)\right\}}} \\
& \text { Keterangan : } \\
& r=\text { Koefisiensi korelasi }
\end{aligned}
$$


$\mathrm{X}=$ Nilai dari butir $(\mathrm{X})$

$\mathrm{Y}=$ Nilai dari total butir(Y)

$\mathrm{N}=$ Banyaknya butir

Apabila $r_{\text {hitung }}>\mathrm{r}_{\text {tabel}}$, maka pengujian item / butir instrumen dinyatakan valid, sebaliknya jika $r_{\text {hitung }}<r_{\text {tabel}}$, maka pengujian item /butir instrument tidak valid. Item pertanyaan yang memiliki $r$ hitung lebih besar dari taraf signifikansi 5\% dianggap tidak valid. Sedangkan item yang mempunyai $r$ hitung lebih kecil dari 5\% dianggap valid (Joko Sulistyo, 2010). Untuk pengujian menentukan signifikan atau tidak signifikan dengan membanding nilai $r$ tabel untuk degree of freedom $=\mathrm{n}-\mathrm{k}$ dalam hal ini 60-2 atau 58 dan satu daerah sisi pengujian dengan alpha 0,1 didapat $r_{\text {tabel }} 0,2144$. Jika rhitung untuk $r$ tiap butir pertanyaan bernilai positif dan lebih besar dari $\mathrm{r}_{\text {tabel }}$ (lihat corrected item-total correlation), maka butir pertanyaan tersebut dikatakan valid.

a) Hasil Uji Validasi Variabel Etika

Tabel

Hasil Uji Validasi Variabel Etika

Item-Total Statistiks

\begin{tabular}{|c|c|c|c|c|}
\hline & $\begin{array}{c}\text { Scale Mean if } \\
\text { Item Deleted }\end{array}$ & $\begin{array}{c}\text { Scale Variance } \\
\text { if Item Deleted }\end{array}$ & $\begin{array}{c}\text { Corrected Item- } \\
\text { Total } \\
\text { Correlation }\end{array}$ & $\begin{array}{c}\text { Cronbach's } \\
\text { Alpha if Item } \\
\text { Deleted }\end{array}$ \\
\hline etika1 & 35.48 & 18.491 & .655 & .914 \\
etika2 & 35.52 & 18.017 & .658 & .914 \\
etika3 & 35.95 & 17.981 & .715 & .910 \\
etika4 & 35.97 & 17.660 & .768 & .907 \\
etika5 & 35.98 & 17.440 & .762 & .908 \\
etika6 & 36.45 & 19.303 & .543 & .919 \\
etika7 & 35.97 & 18.033 & .729 & .910 \\
etika8 & 35.95 & 17.506 & .817 & .905 \\
etika9 & 35.85 & 16.977 & .832 & .903 \\
etika10 & 35.38 & 18.986 & .498 & .922 \\
\hline
\end{tabular}

Sumber : hasil pengolahan data, 2019

Berdasarkan tabel diatas, dapat diketahui bahwa kesepuluh butir pertanyaan pada variabel etika memiliki nilai siginifikan rhitung yang lebih besar dari $r$ tabel, sehingga 10 item pertanyaan tersebut dinyatakan valid.

b) Hasil Uji Validasi Variabel Kompetensi

Tabel

Hasil Uji Validasi Variabel Kompetensi Item-Total Statistiks

\begin{tabular}{|l|r|r|r|r|}
\hline & $\begin{array}{c}\text { Scale Mean if } \\
\text { Item Deleted }\end{array}$ & $\begin{array}{c}\text { Scale Variance } \\
\text { if Item Deleted }\end{array}$ & $\begin{array}{c}\text { Corrected Item- } \\
\text { Total } \\
\text { Correlation }\end{array}$ & $\begin{array}{c}\text { Cronbach's } \\
\text { Alpha if Item } \\
\text { Deleted }\end{array}$ \\
\hline kompetensi1 & 32.37 & 9.728 & .701 & .817 \\
kompetensi2 & 32.33 & 9.718 & .623 & .823 \\
kompetensi3 & 32.60 & 9.397 & .645 & .820 \\
kompetensi4 & 34.10 & 11.719 & .040 & .871 \\
kompetensi5 & 32.58 & 9.874 & .601 & .825 \\
kompetensi6 & 32.67 & 9.616 & .627 & .822 \\
kompetensi7 & 32.75 & 9.140 & .740 & .810 \\
kompetensi8 & 33.10 & 9.278 & .682 & .816 \\
kompetensi9 & 34.25 & 11.343 & .169 & .860 \\
kompetensi10 & 32.50 & 9.983 & .599 & .826 \\
\hline
\end{tabular}

Berdasarkan tabel diatas, terdapat 2 item pertanyaan yang memiliki $\mathrm{r}$ hitung kurang dari $r$ tabel, yaitu pertanyaan nomor 4 dan pertanyaan nomor 9 dengan nilai 0,040 dan 0,169, selebihnya 8 item memiliki nilai rhitung yang lebih besar dari $r$ tabel, sehingga dapat 
disimpulkan bahwa dari 10 pertanyaan pada variabel kompetensi, terdapat 8 item yang dinyatan valid dan 2 item yaitu pertanyaan nomor 4 dan 9 dinyatakan tidak valid / gugur.

c) Hasil Uji Validasi Variabel Pengalaman

Tabel

Hasil Uji Validasi Variabel Pengalaman

Item-Total Statistiks

\begin{tabular}{|l|r|r|r|r|}
\hline & $\begin{array}{c}\text { Scale Mean if } \\
\text { Item Deleted }\end{array}$ & $\begin{array}{c}\text { Scale Variance } \\
\text { if Item Deleted }\end{array}$ & $\begin{array}{c}\text { Corrected Item- } \\
\text { Total } \\
\text { Correlation }\end{array}$ & $\begin{array}{c}\text { Cronbach's } \\
\text { Alpha if Item } \\
\text { Deleted }\end{array}$ \\
\hline pengalaman1 & 33.03 & 12.270 & .711 & .863 \\
pengalaman2 & 33.20 & 12.332 & .740 & .861 \\
pengalaman3 & 32.58 & 12.417 & .757 & .860 \\
pengalaman4 & 32.63 & 12.812 & .692 & .865 \\
pengalaman5 & 33.25 & 12.055 & .720 & .862 \\
pengalaman6 & 33.43 & 11.877 & .693 & .864 \\
pengalaman7 & 34.77 & 14.758 & .155 & .898 \\
pengalaman8 & 34.90 & 15.041 & .108 & .898 \\
pengalaman9 & 33.18 & 11.813 & .768 & .858 \\
pengalaman10 & 33.07 & 12.334 & .688 & .864 \\
\hline
\end{tabular}

Sumber : hasil pengolahan data, 2019

Berdasarkan tabel diatas, terdapat 2 item pertanyaan yang memiliki rhitung kurang dari $r$ tabel, yaitu pertanyaan nomor 7 dan pertanyaan nomor 8 dengan nilai 0,155 dan 0,108 , selebihnya 8 item memiliki nilai $\mathrm{r}$ hitung yang lebih besar dari $\mathrm{r}$ tabel, sehingga dapat disimpulkan bahwa dari 10 pertanyaan pada variabel pengalaman, terdapat 8 item yang dinyatan valid dan 2 item yaitu pertanyaan nomor 7 dan 8 dinyatakan tidak valid / gugur.

d) Hasil Uji Validasi Variabel Kualitas

Tabel

Hasil Uji Validasi Variabel Kualitas Laporan Keuangan Item-Total Statistiks

\begin{tabular}{|l|r|r|r|r|}
\hline & $\begin{array}{c}\text { Scale Mean if } \\
\text { Item Deleted }\end{array}$ & $\begin{array}{c}\text { Scale Variance } \\
\text { if Item Deleted }\end{array}$ & $\begin{array}{c}\text { Corrected Item- } \\
\text { Total } \\
\text { Correlation }\end{array}$ & $\begin{array}{c}\text { Cronbach's } \\
\text { Alpha if Item } \\
\text { Deleted }\end{array}$ \\
\hline kualitas1 & 34.43 & 11.436 & .593 & .876 \\
kualitas2 & 34.87 & 10.151 & .707 & .866 \\
kualitas3 & 34.45 & 11.167 & .590 & .876 \\
kualitas4 & 34.40 & 10.719 & .628 & .873 \\
kualitas5 & 34.42 & 10.518 & .687 & .868 \\
kualitas6 & 34.50 & 11.068 & .560 & .879 \\
kualitas7 & 34.53 & 11.440 & .592 & .876 \\
kualitas8 & 34.53 & 10.795 & .696 & .867 \\
kualitas9 & 34.40 & 11.125 & .685 & .869 \\
\hline
\end{tabular}

Sumber : hasil pengolahan data, 2019

Berdasarkan tabel diatas, dapat diketahui bahwa kesembilan butir pertanyaan pada variabel kualitas laporan keuangan memiliki nilai siginifikan rhitung yang lebih besar dari $r$ tabel, sehingga 9 item pertanyaan tersebut dinyatakan valid.

\section{Uji Reliabilitas}

Reliabilitas adalah alat untuk mengukur suatu kuesioner yang merupakan indikator dari variabel atau konstruk. Pengujian ini bertujuan untuk mengetahui sejauh mana pengukuran data memberikan hasil yang relatif konsisten bila dilakukan pengukuran ulang subyek yang sama. Pengukuran reliablitas ini menggunakan rumus alpha, dengan formula sebagai berikut (Arikunto, 2000)

$$
\text { Rumus : } \quad r_{11}=\left[\frac{k}{k-1}\right]\left[1-\frac{\sum \alpha b^{2}}{a^{\frac{1}{2}}}\right]
$$


Dimana :

$r_{11}=$ reliablitas instrument

$\mathrm{k} \quad$ = banyaknya butir pertanyaan atau banyaknya soal

$\sum \alpha_{1}^{2}=$ Jumlah varians butir

$\alpha_{1}^{2}=$ varians butir total

Hasil uji reliablitas akan dinyatakan benar-benar realiable jika $\mathrm{r}$ yang dihasilkan $\geq 0,7$ dan digunakan taraf signifikan 5\%.

Tabel

Hasil Uji Reliabilitas

\begin{tabular}{|l|l|l|l|}
\hline No & Variabel & $\begin{array}{l}\text { Cronbach's } \\
\text { Alpha }\end{array}$ & Keterangan \\
\hline 1. & Etika & 0,920 & Reliabel \\
\hline 2. & Kompetensi & 0,845 & Reliabel \\
\hline 3. & Pengalaman & 0,882 & Reliabel \\
\hline 4. & $\begin{array}{l}\text { Kualitas Laporan } \\
\text { Keuangan }\end{array}$ & 0,885 & Reliabel \\
\hline
\end{tabular}

Sumber : Data primer yang diolah 2019

Berdasarkan tabel diatas, dapat dilihat bahwa koefisien Cronbach's alpha semua variabel diatas rtabel yaitu variabel etika sebesar 0,920, kompetensi sebesar 0,845 pengalaman 0,882 dan kualitas laporan keuangan sebesar 0,885. Data tersebut menunjukkan bahwa masing-masing variabel memiliki tingkat reliablitas yang sangat tinggi pada semua variabel. Sehingga dapat disimpulkan bahwa instrument yang digunakan dalam penelitian ini adalah realible dan dapat digunakan untuk penelitian selanjutnya.

\section{Uji Asumsi Klasik}

\section{Uji Normalitas}

Uji normalitas bertujuan untuk menguji apakah dalam model regresi, variabel pengganggu atau residual memiliki distribusi normal. Pada penelitian ini, uji normalitas yang digunakan untuk menguji normalitas data yaitu uji chi Kuadrat dengan taraf signifikansi 5. Mengenai perolehan hasil dari uji normalitas tersebut ditunjukan dengan jika nilai probabalitas (sig) $>0,05$, maka distribusi data dikatakan normal. Sebaliknya jika nilai (sig) < 0,05 maka distribusi data dinyatakan tidak normal. Berikut adalah hasil dari uji normalitas yang penulis lakukan :

Tabel

Hasil Uji Normalitas

\begin{tabular}{|l|l|l|l|}
\hline \multicolumn{1}{|c|}{ Variabel } & \multicolumn{1}{c|}{ Chi Kuadrat } & \multicolumn{1}{c|}{ Signifikansi } & \multicolumn{1}{c|}{ Keterangan } \\
\hline Etika & 27,400 & 0,072 & Normal \\
\hline Kompetensi & 14,200 & 0,360 & Normal \\
\hline Pengalaman & 16,267 & 0,365 & Normal \\
\hline Kualitas Laporan & 11,000 & 0,686 & Normal \\
\hline
\end{tabular}

Sumber : Data primer yang diolah 2019

Hasil uji normalitas menggunakan uji chi kuadrat tersebut menunjukkan bahwa semua variabel mempunyai nilai signifikansi lebih besar dari 0,05 . Sehingga dapat disimpulkan bahwa data yang digunakan dalam penelitian ini terdistribusi secara normal. 


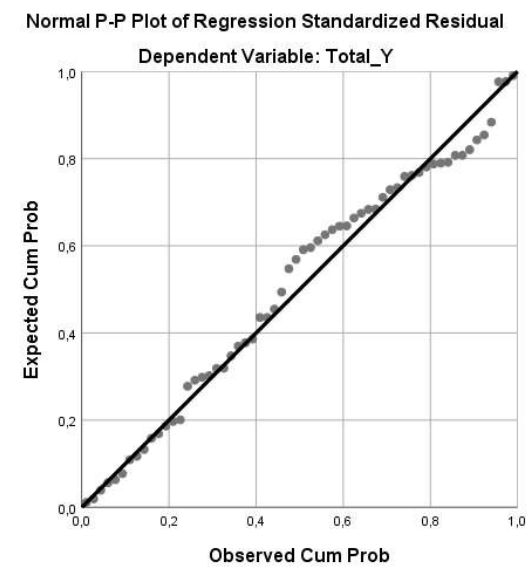

Gambar P-P Plot Normalisasi

Hasil diagram P-P Plot yang juga merupakan output dari pengolahan data penelitian, menunjukkan data terdistribusi atau titik menyebar disekitar garis diagonal dan mengikuti arah garis diagonal penyebaran data yang mengikuti garis lurus, sehingga dapat disimpulkan bahwa data penelitian menunjukan distribusi yang normal.

\section{Uji Multikolinearitas}

Menurut Imam Ghozali (2011), uji multikolinearitas bertujuan untuk menguji apakah model regresi ditemukan adanya kolerasi antar variabel bebas (independen). Model regresi yang baik seharusnya tidak terjadi kolerasi diantara variabel independen.

Adapun hasil uji Multikolinearitas terhadap data penelitian adalah sebagai berikut :

\section{Tabel}

Hasil Uji Multikolinearitas

\begin{tabular}{|l|l|l|l|}
\hline \multicolumn{4}{|c|}{ Variabel Dependen $=$ Kualitas } \\
\hline \multicolumn{1}{|c|}{ Variabel } & \multicolumn{1}{|c|}{ Toleransi } & \multicolumn{1}{c|}{ VIF } & \multicolumn{1}{c|}{ Keterangan } \\
\hline Etika & 0,735 & 1,360 & Non Multikolinearitas \\
\hline Kompetensi & 0,714 & 1,400 & Non Multikolinearitas \\
\hline Pengalaman & 0,966 & 1,035 & Non Multikolinearitas \\
\hline
\end{tabular}

Dasar Pengembilan keputusan uji Multikolinearitas adalah :

a. Jika nilai tolerance $>0,10$ maka artinya tidak terjadi multikolinearitas.

b. Jika nilai VIF $<10,00$ maka artinya tidak terjadi multikolinearitas.

Dari hasil uji Multikolinearitas di atas, nilai tolerance menunjukan nilai yang lebih besar dari 0,10 yaitu variabel Etika sebesar 0,735, variabel kompetensi sebesar 0,714 dan variabel pengalaman sebesar 0,966 . Sementara untuk angka variance inflaction faktor (VIF) semua variabel independent memiliki nilai lebih kecil dari 10, dimana Etika memiliki angka sebesar 1,360, kompetensi memiliki angka 1,400 dan pengalaman memiliki angka sebesar 1,035. Dengan demikian dapat dikatakan bahwa model regresi yang digunakan dalam penelitian ini tidak terjadi adanya gejala multikolinearitas antar variabel independen.

\section{Uji Heteroskedastisitas}

Uji ini digunakan untuk mengetahui apakah setiap nilai variabel independen berpasangan dengan variabel dependen mempunyai distribusi dan varians yang sama atau tidak. Uji heteroskedastitas yang digunakan dalam penelitian ini adalah uji korelasi jenjang Spearman. Apabila nilai koefisian signifikansi yang didapat dari perhitungan hasil uji heteroskedastitas pada masing masing variabel lebih besar dari pada nilai alpha yang telah ditetapkan yaitu 0,05. Maka data yang digunakan dalam penelitian tidak terjadi adanya 
heteroskedastitas, dan sebaliknya. Hasil uji heteroskedastitas menggunakan uji spearman disajikan pada tabel dibawah ini.

Tabel

\begin{tabular}{|c|c|c|c|c|c|c|c|c|}
\hline \multirow[b]{3}{*}{ Model } & & \multicolumn{7}{|c|}{$\begin{array}{l}\text { Hasil Uji Heteroskedastisitas } \\
\text { Coefficients }^{\mathrm{a}}\end{array}$} \\
\hline & & \multicolumn{2}{|c|}{ Unstandardized Coefficients } & \multirow{2}{*}{$\begin{array}{c}\text { Standardized } \\
\text { Coefficients } \\
\text { Beta }\end{array}$} & \multirow[b]{2}{*}{$\mathrm{t}$} & \multirow[b]{2}{*}{ Sig. } & \multicolumn{2}{|c|}{ Collinearity Statistics } \\
\hline & & B & Std. Error & & & & Tolerance & VIF \\
\hline 1 & (Constant) & 2,751 & 4,594 & & ,599 & ,552 & & \\
\hline & Total_X1 &, 139 &, 084 & 177 & 1,664 &, 102 & ,735 & 1,360 \\
\hline & Total X2 & ,508 &, 114 & ,483 & 4,473 &, 000 &, 714 & 1,400 \\
\hline & Total X3 & 322 &, 087 & ,344 & 3,701 &, 000 & ,966 & 1,035 \\
\hline
\end{tabular}

Berdasarkan hasil perhitungan pada tabel diatas menunjukkan bahwa nilai koefisiensi signifikansi pada masing-masing variabel lebih besar dari pada 0,05 , yaitu variabel etika sebesar 0,102, variabel kompetensi sebesar 0,000 dan variabel pengalaman sebesar 0,000. Sehingga dapat disimpulkan bahwa data yang digunakan dalam penelitian ini tidak ditemukan adanya heteroskedastitas.

\section{Uji Autokorelasi}

Uji autokorelasi dalam penelitian ini dengan menggunakan uji Durbin Watson. Nilai Durbin Watson yang berada diantara nilai du dan 4-du menunjukkan model yang tidak terkena masalah autokorelasi. Hasil penelitian dengan menggunakan uji tersebut dapat dilihat pada tabel sebagai berikut :

\begin{tabular}{|c|c|c|c|c|c|}
\hline \multirow[b]{2}{*}{ Model } & \multicolumn{5}{|c|}{$\begin{array}{c}\text { Tabel } \\
\text { Uji Autokorelasi } \\
\text { Model Summary }^{\mathbf{b}}\end{array}$} \\
\hline & $\mathrm{R}$ & R Square & Adjusted R Square & $\begin{array}{l}\text { Std. Error of the } \\
\text { Estimate }\end{array}$ & Durbin-Watson \\
\hline 1 &, $730^{\mathrm{a}}$ & ,534 & ,509 & 2,590 & 1,990 \\
\hline
\end{tabular}

Berdasarkan tabel diatas dapat diketahui bahwa nilai durbin watson adalah 1,990. Jika nilai durbin watson tersebut diantara du dan 4-du ( $\mathrm{du}<\mathrm{d}<4$-du $)$ maka tidak terjadi masalah autokorelasi.

\section{Tabel}

Hasil Uji Autokorelasi dengan Durbin Watson (DW Test)

\begin{tabular}{|c|c|c|c|c|}
\hline Autokorelasi positf & Daerah ragu-ragu & $\begin{array}{l}\text { Tidak ada } \\
\text { autokorelasi }\end{array}$ & Daerah ragu-ragu & Autkorelasi negative \\
\hline 0 & $d l$ & $d u$ & $4-d u$ & $4-d l$ \\
1,32 & 1,466 & 2,534 & 2,68 \\
& & & &
\end{tabular}

$$
\text { Nilai DW }=1,990
$$

Berdasarkan tabel diatas hasil uji autokorelasi dengan durbin watson diatas menunjukkan bahwa nilai durbin watson 1,990 berada diantara nilai du dan 4-du, maka dapat disimpulkan bahwa tidak terjadi masalah autokorelasi.

\section{Analisis Regresi Linier Berganda}

Analisis regresi berganda digunakan untuk menguji dua pengaruh atau lebih variabel independen terhadap variabel dependen. Analisis regresi berganda juga bertujuan untuk mengestimasi dan memprediksi nilai rata-rata variabel dependen berdasarkan nilai variabel 
independen yang diketahui. Analisis ini juga mengukur kekuatan hubungan atara dua variabel atau lebih dan menunjukkan hubungan antara variabel independen dengan variabel dependen. Adapun persamaan regresinya linier seperti pada tabel dibawah ini:

\section{Tabel}

\begin{tabular}{|c|c|c|c|c|c|c|c|c|}
\hline & & \multicolumn{7}{|c|}{$\begin{array}{l}\text { Hasil Uji Regresi Linier Berganda } \\
\text { Coefficients }^{\mathrm{a}}\end{array}$} \\
\hline \multirow{2}{*}{\multicolumn{2}{|c|}{ Model }} & \multicolumn{2}{|c|}{ Unstandardized Coefficients } & \multirow{2}{*}{$\begin{array}{c}\text { Standardized } \\
\text { Coefficients } \\
\text { Beta }\end{array}$} & \multirow[b]{2}{*}{$\mathrm{t}$} & \multirow[b]{2}{*}{ Sig. } & \multicolumn{2}{|c|}{ Collinearity Statistics } \\
\hline & & $\mathrm{B}$ & Std. Error & & & & Tolerance & VIF \\
\hline \multirow[t]{4}{*}{1} & (Constant) & 2,751 & 4,594 & &, 599 & ,552 & & \\
\hline & Total_X1 & ,139 &, 084 &, 177 & 1,664 &, 102 &, 735 & 1,360 \\
\hline & Total_X2 &, 508 &, 114 & ,483 & 4,473 &, 000 & ,714 & 1,400 \\
\hline & Total X3 &, 322 &, 087 & ,344 & 3,701 &, 000 & ,966 & 1,035 \\
\hline
\end{tabular}

Sumber: data primer yang diolah, 2019

Berdasarkan tabel diatas hasil analisis regresi diatas maka diperoleh persamaan sebagai berikut :

$$
\mathrm{Y}=2,751+0,139 \mathrm{X}_{1}+0,508 \mathrm{X}_{2}-0,322 \mathrm{X}_{3}
$$

Dari persamaan tersebut bisa diambil kesimpulan sebagai berikut:

1. Nilai konstanta sebesar 2,751 dapat diartikan bahwa variabel kualitas laporan keuangan akan mengalami peningkatan sebesar 2,751 tanpa adanya pengaruh dari variabel etika, kompetensi dan pengalaman.

2. Nilai koefisiensi pada variabel etika (X1) sebesar 0,139 artinya bahwa setiap perubahan variabel etika sebesar satu satuan dengan asumsi varibel lainnya dianggap konstan, maka kualitas laporan keuangan sebesar 0,139 atau sebesar 13,9\%.

3. Nilai koefisiensi pada variabel kompetensi (X2) sebesar 0,508 artinya bahwa setiap perubahan variabel kompetensi sebesar satu satuan dengan asumsi varibel lainnya dianggap konstan, maka kualitas laporan keuangan sebesar 0,508 atau sebesar 50,8\%.

4. Nilai koefisiensi pada variabel pengalaman (X3) sebesar 0,322 artinya bahwa setiap perubahan variabel pengalaman sebesar satu satuan dengan asumsi varibel lainnya dianggap konstan, maka kualitas laporan keuangan sebesar 0,322 atau sebesar 32,2\%.

\section{Uji Koefisien Determinasi}

Koefisien determinasi (Adjusted $\mathrm{R}^{2}$ ) digunakan untuk mengetahui sejauh mana kontribusi variabel independen terhadap variabel dependen dengan adanya regresi linier berganda. Semakin besar nilai $\mathrm{r}^{2}$ digunakan maka semakin besar variasi sumbangannya terhadap variabel terikat. Adapun hasil dari analisis koefisien determinasi pada penelitian ini adalah sebagai berikut:

\section{Tabel}

\section{Hasil Analisis Koefisien Determinasi $\left(\mathbf{R}^{2}\right)$} Model Summary

\begin{tabular}{|c|c|c|c|c|c|}
\hline Model & $\mathrm{R}$ & R Square & Adjusted R Square & $\begin{array}{l}\text { Std. Error of the } \\
\text { Estimate }\end{array}$ & Durbin-Watson \\
\hline$\overline{1}$ &, $730^{\mathrm{a}}$ & ,534 & ,509 & 2,590 & 1,990 \\
\hline
\end{tabular}

b. Dependent Variable: Total $\bar{Y}$

Sumber: data primer yang diolah, 2019

Tabel diatas menunjukkan angka Adjusted R Square sebesar 0.509 atau sebesar $50,9 \%$. Hal ini menunjukkan bahwa kualitas laporan keuangan pemerintah daerah dipengaruhi oleh variabel etika, kompetensi dan pengalaman dalam mengelola barang milik daerah sebesar $50,9 \%$, sedangkan sisanya sebesar $49,1 \%$ dipengaruhi oleh variabel lain yang tidak termasuk dalam penelitian ini. 


\section{Uji t}

Uji parsial digunakan untuk mengetahui pengaruh masing-masing variabel independen terhadap variabel dependen. Menentukan tingkat signifikan $(\alpha)$ yaitu sebesar 5\% dapat dilakukan dengan berdasarkan nilai probabilitas, dengan cara pegambilan keputusan adalah:

a) Jika nilai probabilitas $>0,05$ maka Ho diterima

b) Jika nilai probabilitas $<0,05$ maka Ho ditolak atau dengan cara melihat tabel $\mathrm{t}$ :

a) Jika $t_{\text {tabel }}<t_{\text {hitung, maka Ha diterima }}$

b) Jika $t$ tabel $>t$ hitung, maka Ho diditerima

Untuk menghitung t-tabel digunakan ketentuan n-1 pada level signifikan $(\alpha)$ sebesar 5\% (tingkat kesalahan 5\% atau 0,05 atau taraf keyakinan 95\%, jadi apabila tingkat kesalahan suatu variabel lebih dari 5\% berarti variabel itu tidak signifikan, berikut adalah hasil analisis uji touput spss uji t:

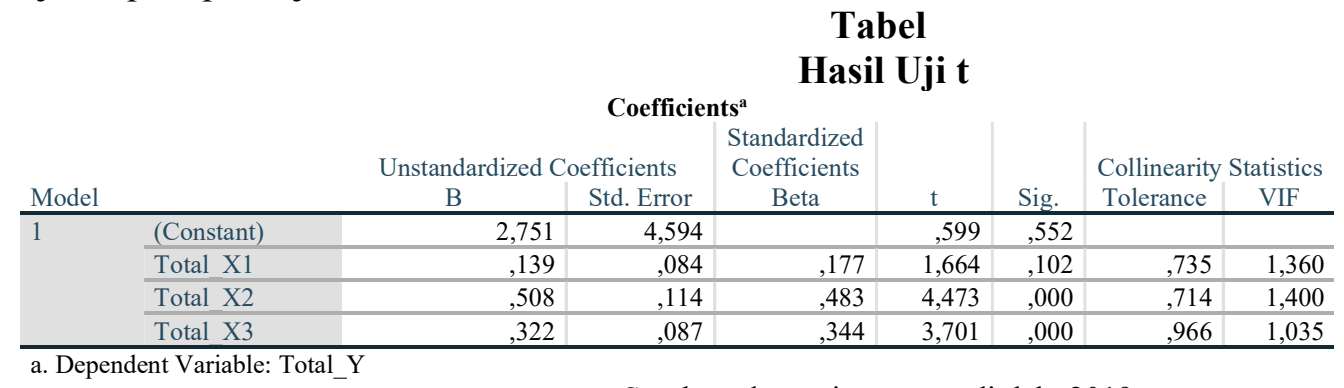

Sumber: data primer yang diolah, 2019

a. Pengaruh Etika dalam mengelola barang milik daerah terhadap kualitas laporan keuangan Uji parsial yang pertama dilakukan untuk mengetahui pengaruh etika dalam mengelola barang milik daerah terhadap kualitas laporan keuangan, adapun hipotesis yang ditetapkan oleh peneliti adalah :

Ho1 : etika dalam mengelola barang milik daerah tidak berpengaruh terhadap kualitas laporan.

Ha1 : etika dalam mengelola barang milik daerah berpengaruh terhadap kualitas laporan. Nilai $\mathrm{t}$ hitung etika dalam mengelola barang milik daerah sebesar 1,664 dengan signifikansi sebesar 0,102 sementara $t$ tabel diperoleh angka 2,00324 ( $\mathrm{t}$ tabel $=\mathrm{t}(\alpha / 2: \mathrm{n}$ $\mathrm{k}-1)=\mathrm{t}(0.025 ; 56)=2,00324)$. Dengan demikian maka t-hitung $<\mathrm{t}$-tabel atau $1,664<$ 2,00324), Hol diterima dan Hal ditolak, yang artinya tidak terdapat pengaruh yang signifikan antara Etika dalam mengelola barang milik daerah terhadap kualitas laporan keuangan. Artinya besar kecilnya kenaikan variabel etika, tidak berpengaruh terhadap kenaikan kualitas laporan keuangan, apabila terjadi penurunan pada variabel etika tidak berpengaruh terhadap kualitas laporan keuangan, begitupun sebaliknya.

b. Pengaruh kompetensi dalam mengelola barang milik daerah terhadap kualitas laporan keuangan

Uji parsial yang kedua dilakukan untuk mengetahui pengaruh kompetensi dalam mengelola barang milik daerah terhadap kualitas laporan keuangan, adapun hipotesis yang ditetapkan oleh peneliti adalah :

Ho2: kompetensi dalam mengelola barang milik daerah tidak berpengaruh terhadap kualitas laporan.

Ha2 : kompetensi dalam mengelola barang milik daerah berpengaruh terhadap kualitas laporan.

Nilai t hitung pengalaman dalam mengelola barang milik daerah sebesar 4,473 dengan signifikansi sebesar 0,000 sementara $\mathrm{t}$ tabel diperoleh angka 2,00324 (t tabel $=\mathrm{t}(\alpha / 2: \mathrm{n}-$ $\mathrm{k}-1)=\mathrm{t}(0.025 ; 56)=2,00324)$. Dengan demikian maka t-hitung $>\mathrm{t}$-tabel atau 4,473 > 2,00324), Ha2 diterima dan Ho2 ditolak, yang artinya terdapat pengaruh yang signifikan 
antara kompetensi dalam mengelola barang milik daerah terhadap kualitas laporan keuangan. Variabel kompetensi memiliki koefisien yang positif yatu sebesar 0,508 yang artinya semakin tinggi kompetensi dalam mengelola barang maka semakin tinggi pula kualitas laporan keuangan pemerintah daerah

c. Pengaruh pengalaman dalam mengelola barang milik daerah terhadap kualitas laporan keuangan

Uji parsial yang kedua dilakukan untuk mengetahui pengaruh pengalaman dalam mengelola barang milik daerah terhadap kualitas laporan keuangan, adapun hipotesis yang ditetapkan oleh peneliti adalah :

Ho3: pengalaman dalam mengelola barang milik daerah tidak berpengaruh terhadap kualitas laporan.

Ha3 : pengalaman dalam mengelola barang milik daerah berpengaruh terhadap kualitas laporan.

Nilai t hitung pengalaman dalam mengelola barang milik daerah sebesar 3,701 dengan signifikansi sebesar 0,000 sementara t tabel diperoleh angka 2,00324 (t tabel $=\mathrm{t}$ $(\alpha / 2: \mathrm{n}-\mathrm{k}-1)=\mathrm{t}(0.025 ; 56)=2,00324)$. Dengan demikian maka t-hitung $>\mathrm{t}$-tabel atau $3,701>2,00324)$, Ha2 diterima dan Ho2 ditolak, yang artinya terdapat pengaruh yang signifikan antara pengalaman dalam mengelola barang milik daerah terhadap kualitas laporan keuangan. Variabel pengalaman juga memiliki koefisien yang positif yatu sebesar 0,322 atau dapat juga dikatan bahwa variabel pengalaman berpengaruh secara positif yang artinya semakin tinggi pengalaman dalam mengelola barang maka semakin tinggi pula kualitas laporan keuangan pemerintah daerah.

\section{Uji F}

Uji simultan dengan $F$ test ini bertujuan untuk mengetahui pengaruh bersama-sama variabel independen terhadap variabel dependen. Uji $\mathrm{F}$ diperuntukan untuk melakukan uji hipotesis koefisien (slope) regresi secara bersamaan. Hipotesis yang ditetapkan oleh penulis adalah :

a. Hipotesis Ho4 : Etika, kompetemsi dan pengalaman dalam mengelola barang milik daerah secara bersama-sama tidak berpengaruh terhadap kualitas laporan keuangan

b. Hipotesis Ha3 : Etika, kompetemsi dan pengalaman dalam mengelola barang milik daerah secara bersama-sama berpengaruh terhadap kualitas laporan keuangan

Menentukan tingkat signifikan $(\alpha)$ yaitu sebesar 5\% dapat dilakukan dengan berdasarkan nilai probabilitas, dengan cara :

a) Jika nilai probabilitas $>0,05$ maka Ho diterima

b) Jika nilai probabilitas $<0,05$ maka Ho ditolak

Atau dengan cara melihat $\mathrm{f}$ hitung dengan $\mathrm{F}$ tabel :

a) Jika $\mathrm{F}_{\text {hitung }}<\mathrm{F}_{\text {tabel }}$, maka Ho diterima

b) Jika $F_{\text {hitung }}>F_{\text {tabel, }}$, maka Ho ditolak

Berikut adalah hasil analisis ouput spss untuk uji simultan :

Tabel

Hasil Uji F

\begin{tabular}{|c|c|c|c|c|c|c|}
\hline \multicolumn{7}{|c|}{$\mathbf{A N O V A}^{\mathrm{a}}$} \\
\hline & & Sum of Squares & df & Mean Square & $\mathrm{F}$ & Sig. \\
\hline \multirow[t]{3}{*}{1} & Regression & 429,460 & 3 & 143,153 & 21,348 &, $000^{\mathrm{b}}$ \\
\hline & Residual & 375,523 & 56 & 6,706 & & \\
\hline & Total & 804,983 & 59 & & & \\
\hline
\end{tabular}

a. Dependent Variable: Total_Y

b. Predictors: (Constant), Total_X3, Total_X1, Total_X2

Sumber: data primer yang diolah, 2019

Dari tabel hasil uji anova atau uji $\mathrm{F}$ pada tabel diatas, menunjukan F-hitung sebesar

21,348 dengan tingkat signifikansi 0,000 sedangkan $\mathrm{F}$-tabel $=2,76$. Dari tabel diatas bisa diketahui bawah F-hitung $>$ F-Tabel $(21,348>2,76)$ dan tingkat signifikansi $0,000<0,05$ maka 
Ha diterima dan Ho ditolak yang artinya bahwa etika, kompetensi dan pengalaman dalam mengelola barang milik daerah secara bersama-sama berpengaruh terhadap kualitas laporan keuangan. Sehingga dapat disimpulkan bahwa semakin tinggi etika, kompetensi dan pengalaman dalam mengelola barang miliki daerah akan semakin tinggi pula kualitas laporan keuangan pemerintah daerah.

\section{Pembahasan dan Interpretasi Penelitian}

Etika dalam mengelola barang milik daerah tidak berpengeruh terhadap kualitas laporan keuangan pemerintah daerah

Hasil dari penelitian ini menunjukkan bahwa etika dalam mengelola barang milik daerah tidak berpengaruh terhadap kualitas laporan keuangan. Hal tersebut ditunjukkan dengan nilai $\mathrm{t}$ hitung $<\mathrm{t}$ tabel yaitu $1,623<2,00324$ dan tingkat signifikansi bernilai $0,110>$ 0,05 .

Nilai t hitung lebih kecil dari pada nilai tabel menunjukkan bahwa etika dalam mengelola barang milik daerah tidak berpengaruh secara signifikan terhadap kualitas laporan keuangan pemerintah daerah Kabupaten Bekasi. Artinya besar kecilnya kenaikan variabel etika, tidak berpengaruh terhadap kenaikan kualitas laporan keuangan, apabila terjadi penurunan pada variabel etika tidak berpengaruh terhadap kualitas laporan keuangan, begitupun sebaliknya. Hasil penelitian terhadap variabel etika diatas tidak sejalan dengan penelitian sebelumnya oleh Rifa'i Aditya yang meneliti pengaruh etika, kompetensi dan pengalaman dalam mengelola barang milik negara terhadap kualitas laporan keuangan pemerintah pusat yang menunjukkan adanya pengaruh etika dalam mengelola barang milik Negara terhadap kualitas laporan keuangan pemerintah pusat.

\section{Kompetensi dalam mengelola barang milik daerah berpengaruh terhadap kualitas laporan keuangan pemerintah daerah}

Hasil dari penelitian ini menunjukkan bahwa kompetensi dalam mengelola barang milik daerah berpengaruh secara signifikan terhadap kualitas laporan keuangan. Hal tersebut ditunjukkan dengan nilai $\mathrm{t}$ hitung $>\mathrm{t}$ tabel yaitu sebesar 4,304 $>2,00324$ dan tingkat signifikansi bernilai $0,000<0,05$.

Kompetensi adalah kemampuan atau keahlian dalam membuat suatu bentuk atau pekerjaan sesuai dengan skill dan pengetahuan berdasarkan keilmuan yang dimiliki dari pendidikan formal dan informal yang membentuk sikap professional dalam bekerja. Hasil penelitian ini sejalan dengan hasil penelitian terdahulu yang dilakukan oleh Rifa'i Aditya (2014) yang menunjukkan adanya pengaruh antara kompetensi dalam mengelola barang milik Negara terhadap kualitas laporan keuangan pemerintah pusat. Hal ini berarti bahwa semakin baik kompetensi para pegawai dalam mengelola barang milik daerah, maka kualitas laporan keuangan juga akan semakin baik, begitu pula sebaliknya.

\section{Pengalaman dalam mengelola barang milik daerah berpengaruh terhadap kualitas laporan keuangan pemerintah daerah}

Hasil dari penelitian ini menunjukkan bahwa pengalaman dalam mengelola barang milik daerah berpengaruh terhadap kualitas laporan keuangan. Hal tersebut ditunjukkan dengan nilai t hitung $>\mathrm{t}$ tabel yaitu sebesar 3,976 > 2,00324 dan tingkat signifikansi bernilai $0,000<0,05$.

Nilai t hitung yang lebih besar dari pada nilai tabel menunjukkan bahwa pengalaman dalam mengelola barang milik daerah berpengaruh secara signifikan terhadap kualitas laporan keuangan pemerintah daerah Kabupaten Bekasi.

Hasil penelitian terhadap variabel pengalaman diatas mendukung penelitian sebelumnya oleh Rifa'i Aditya (2014) yang menunjukkan adanya pengaruh pengalaman 
dalam mengelola barang milik negara terhadap kualitas laporan keuangan pusat, serta sejalan dengan penelitian yang dilakukan oleh Utomo Ari (2017) yang menunjukkan bahwa pengalaman berpengaruh positif terhadap kualitas laporan keuangan daerah. Hasil penelitian ini menjelaskan bahwa semakin lama menjadi pengurus barang ataupun pengurus barang pembantu, maka semakin mengerti dalam memperoleh data yang dibutuhkan dalam penyusunan laporan. Semakin banyak wawasan dan memiliki pertimbangan yang lebih matang, terkait pengambilan keputusan pada saat terjadi permasalahan, sehingga dapat disimpulkan bahwa semankin banyaknya pengalaman yang diperoleh pegawai dalam mengelola barang milik daerah maka semakin tinggi kualitas laporan keuangan yang dihasilkan.

Etika, kompetensi dan pengalaman berpengaruh secara bersama-sama terhadap kualitas laporan keuangan pemerintah daerah

Hasil penelitian ini menunjukkan F-hitung sebesar 21,461 dengan tingkat signifikansi 0,000 sedangkan $\mathrm{F}$-tabel $=2,76$. Hal ini berartinya bahwa etika, kompetensi dan pengalaman dalam mengelola barang milik daerah secara bersama-sama berpengaruh terhadap kualitas laporan keuangan pemerintah daerah.

Hasil penelitian secara stimultan tersebut juga memiliki hasil yang sama dengan penelitian sebelumnya oleh Rifa'i Aditya (2014) yang menunjukkan adanya pengaruh etika, kompetensi dan pengalaman dalam mengelola barang milik negara secara bersama-sama terhadap kualitas laporan keuangan pusat. Laporan keuangan merupakan suatu bentuk pertanggungjawaban pemerintah daerah dari transaksi keuanga yang terjadi selama satu tahun / satu periode buku bersangkutan. Laporan keuangan yang berkualitas menurut SAP harus mengandung beberapa indikator yang meliputi dapat dipahami (undestandability), relevansi (relevance), keterandalan (reliable) dan dapat diperbandingkan (comparibility).

\section{Kesimpulan}

\section{KESIMPULANDAN SARAN}

Berdasarkan hasil penelitian dan pembahasan mengenai pengaruh Etika, Kompetensi dan Pengalaman dalam Mengelola Barang Milik Daerah terhadap Kualitas Laporan Keuangan Pemerintah Daerah Kabupaten Bekasi maka dapat diambil kesimpulan dalam penelitian ini sebagai berikut :

1. Tidak terdapat pengaruh yang signifikan antara variabel etika dalam mengelola barang milik daerah terhadap kualitas laporan keuangan pemerintah daerah Kabupaten Bekasi.

2. Terdapat pengaruh yang signifikan antara variabel kompetensi dalam mengelola barang milik daerah terhadap kualitas laporan keuangan pemerintah daerah Kabupaten Bekasi.

3. Terdapat pengaruh yang signifikan antara variable pengalaman dalam mengelola barang milik daerah terhadap kualitas laporan keuangan pemerintah daerah Kabupaten Bekasi.

4. Secara simultan variabel etika, kompetensi dan pengalaman dalam mengelola barang milik daerah berpengaruh signifikan terhadap kualitas laporan keuangan pemerintah daerah Kabupaten Bekasi.

\section{Saran}

1. Bagi Pemerintah Daerah Kabupaten Bekasi diharapkan dapat mempertimbangkan hasil penelitian ini, sebagai acuan dalam melakukan analisis pengelolaan barang milik daerah untuk meningkatkan kualitas laporan keuangan pemerintah daerah Kabupaten Bekasi

2. Bagi Peneliti berikutnya dimasa mendatang untuk dapat meneliti faktor lain yang diduga memiliki pengaruh terhadap kualitas laporan keuangan pemerintah daerah, mengingat variable dalam penelitian ini memberikan kontribusi sebesa $50,9 \%$, sehingga sisanya yang sebesar $49,1 \%$ tersebut dapat diketahui melalui penelitian yang akan datang. 


\section{DAFTAR PUSTAKA}

Abdul Halim, dkk. 2012. “Akuntansi Sektor Publik Akuntansi Keuangan Daerah". Edisi 4. Jakarta : Salemba Empat

Baridwan, Zaki, 2000. "Intermedite Accounting”, BPFE, Yogyakarta

Bastian, Indra. 2002. "Sistem Akuntansi Sektor Publik”. Jakarta : Salemba Empat

Ghozali, Imam. 2009. “Aplikasi Analisis Multivariate Dengan Program SPSS edisi 3

Hadi, Sutrisno, 2004. "Metodologi Research Jilid 3". Yogyakarta :Andi

Indriantoro, Nur. 2009. "Metodologi Penelitian Bisnis untuk Akuntansi dan Manajemen, Edisi Pertama". Yogyakarta :BPFE, Yogyakarta

KH. Hilmah Fairoza. 2013. "Analisis pelaksanaan penatausahaan dan akuntansi aset tetap pada DPKAD Kota Padang". Fak. Ekonomi Universitas Padang

Kuncoro, Udi. 2017. "Pengaruh Kompetensi Sumber Daya Manuasia dan Penerapan Sistem Informasi Manajemen Daerah (SIMDA) Terhadap Kualitas Laporan Keuangan Pemerintah Daerah." Fakultas Ekonomi dan Bisnis. Universitas Lampung Bandar Lampung.

M. Yusuf. 2015. "Langkah Pengelolaan Aset Daerah Menuju Pengelolaan Keuangan Daerah Terbaik”. Jakarta : Salemba Empat.

Nordiawan, Dedi. 2010. "Akuntansi Sektor Publik". Jakarta: Salemba Empat

Purwanto, Erwan dan Sulistyastuti. 2015. "Metodologi Penelitian Kuantitatif Untuk Administrasi Publik dan Masalah-Masalah Sosial". Jogjakarta: Gava Media

Republik Indonesia. 2018. Peraturan Bupati Bekasi Nomor 35 Tahun 2018 tentang Petunjuk Teknis Pengelolaan Barang Milik Daerah

Republik Indonesia. 2007. Peraturan Menteri Dalam Negeri Nomor 17 tahun 2007 tentang Pedoman Teknis Pengelolaan Barang Milik Daerah

Republik Indonesia. 2016. Peraturan Menteri Dalam Negeri Nomor 19 tahun 2016 tentang Penatausahaan Barang Milik Daerah

Republik Indonesia. 2007. Peraturan Menteri Dalam Negeri Nomor 59 Tahun 2007 tentang Pedoman Pengelolaan Keuangan Daerah

Republik Indonesia. 2014. Peraturan Pemerintah Republik Indonesia Nomor 27 Tahun 2014 tentang Pengelolaan Barang Milik Daerah / Negara

Republik Indonesia. 2010. Peraturan Pemerintah Republik Indonesia Nomor 71 Tahun 2010 tentang Standar Akuntansi Pemerintah

Republik Indonesia. 2016. Peraturan Daerah Kabupaten Bekasi Nomor 10 Tahun 2011 tentang Pengelolaan Barang Milik Daerah

Rifai'I, Aditya. 2014. "Pengaruh Etika, Kompetensi dan Pengalaman dalam Mengelola Barang Milik Negara (BMN) terhadap Kualitas Laporan Keuangan Pemerintah Pusat”. Fakultas Ekonomi Universitas Yogyakarta

Sekaran, Uma. 2009. "Metodologi Penelitian untuk Bisnis". Jakarta : Salemba Empat

Siregar, Baldric. 2015. “Akuntansi Sektor Publik (Akuntansi Keuangan Pemerintah Daerah Berbasis Akrual)".Yogyakarta :UPP-STIM YKPN

Sugiyogo. 2018. "Metode Penelitian Kuantitatif, Kualitatif dan R\&D". Cetakan ke -27, Bandung: Alfabeta

Utomo, Ari. 2017. “Pengaruh Kompetensi dan Pengalaman Dalam Mengelola Barang Milik Daerah Terhadap Kualitas Laporan Keuangan Daerah Dengan Etika Sebagai Variabel Moderating”. Fakultas Ekonomi dan Bisnis Islam UIN Alauddin Makasar 